Author: J Barnard

THE INFLUENCE OF THE CONSUMER PROTECTION ACT 68 OF 2008 ON THE COMMON LAW WARRANTY AGAINST EVICTION: A COMPARATIVE OVERVIEW

2012 VOLUME 15 No 5 


\section{THE INFLUENCE OF THE CONSUMER PROTECTION ACT 68 OF 2008 ON THE COMMON LAW WARRANTY AGAINST EVICTION: A COMPARATIVE OVERVIEW}

J Barnard ${ }^{\star}$

\section{Introduction}

The implementation of the Consumer Protection Act 68 of $2008^{1}$ has great implications for the South African common law of sale. In this contribution the influence of the CPA on the seller's common law duty to warrant the buyer against eviction is investigated. Upon evaluation of the relevant provisions of the CPA, the legal position in the United Kingdom - specifically the provisions of the Sales of Goods Act of $1979^{2}$ - is investigated.

\section{Brief summary of the South African common law position}

Eviction can be defined as any action by a third party who has better rights to the merx than the buyer, and who deprives the buyer of the total or partial use, enjoyment and disposal of the merx. ${ }^{3}$ The duty of the seller to provide undisturbed use and enjoyment of the merx has two facets, ${ }^{4}$ namely, that the seller undertakes that he will not himself engage in any conduct which will disturb the buyer in his use and enjoyment of the things sold, ${ }^{5}$ and that the buyer will not be evicted from the merx by a third person. ${ }^{6} \mathrm{Kahn}^{7}$ states that the disturbance of possession by a third party covered by the warranty is limited to a person asserting a stronger entitlement to perma-

\footnotetext{
* Jacolien Barnard. LLB, LLM. Senior Lecturer, Department of Mercantile Law, University of Pretoria. Email: jacolien.barnard@up.ac.za.

1 Hereinafter referred to as the CPA or the Act.

2 Hereinafter referred to as SOGA.

3 Nagel Commercial Law 219. See also Lammers and Lammers v Giovannoni 19553 SA 385 (A); Lavers v Hein \& Far BK 19972 SA 396 (T); Alpha Trust (Edms) Bpk v Van der Watt 19753 SA 734 (A).

4 Sharrock Business Transactions Law 290.

5 See Becker \& Co (Pty) Ltd v Becker 19813 SA 406 (A), where the court confirmed that the seller is liable for breach of contract if he does anything which directly or indirectly detracts from the buyer's right of use and enjoyment of the merx.

6 Contra Kerr 1999 SALJ 455-462, where the writer refers to Roman-Dutch writers such as Voet and Van Leeuwen and argues that only a third party (and not the seller) can evict the buyer from his possession of the merx.

7 Kahn Principles of Sale and Lease 27.
} 
nent possession of the merx than the buyer acquired from the seller and that this is often referred to as a 'superior title'.

The duty of the seller to warrant the buyer against eviction does not include a warranty for the transfer of ownership and the seller is therefore also not obliged to transfer ownership. ${ }^{8}$ The warranty forms part of the implied terms or naturalia of a contract of sale and does not have to be contained in an express warranty in the agreement. ${ }^{9}$ The reason for the eviction must exist at the time of the conclusion of the contract, and where eviction is not imminent and merely a threat the buyer will have no cause of action against the seller. ${ }^{10}$ Sharrock gives the example of a buyer losing possession due to the execution of a writ of attachment issued against the seller. ${ }^{11}$ Where, however, a buyer is deprived of his possession as a result of the activities of squatters or a thief this will not amount to eviction. ${ }^{12}$

In Vrystaat Motors $v$ Henry Blignaut (Edms) Bpk, ${ }^{13}$ it was held that where a temporary deprivation of possession has become permanent, eviction has taken place. Similarly in Lavers $v$ Hein \& Far $B K^{14}$ the motor vehicle bought by the bona fide buyer was temporarily seized as part of an on-going investigation of possible theft. The motor vehicle turned out to be stolen property and the temporary eviction became permanent.

\subsection{Forms of eviction}

The forms of eviction encountered in South African case law include the instances where the true owner of the merx claims his property from the buyer; ${ }^{15}$ a third party obtained possession of the merx and the buyer cannot reclaim it due to his defective

\footnotetext{
$8 \quad$ Nagel Commercial Law 213.

$9 \quad$ Nagel Commercial Law 219.

10 Kahn Principles of Sale and Lease 26-27.

11 Sharrock Business Transactions Law 290.

12 Sharrock Business Transactions Law 290.

13 Vrystaat Motors v Henry Blignaut (Edms) Bpk 19962 SA 448 (A).

14 Lavers $v$ Hein \& Far BK 19972 SA 396 (T).

15 Mdakane v Standard Bank of South Africa Ltd 19991 SA 127 (W).
} 
title; ${ }^{16}$ and where the holder of a limited real right prevents the buyer from having full use and enjoyment of the merx. ${ }^{17}$

\subsection{Duties of the buyer when eviction becomes imminent}

Although it is correct that the buyer has no right of recourse where he is merely threatened with eviction, it is perhaps more accurate to say that the buyer does not have a right of recourse in the period during which ${ }^{18}$ he is merely threatened ${ }^{19}$ with eviction. The buyer needs to follow certain rules in the period when he is threatened with eviction. ${ }^{20}$ If he does not follow the rules when eviction is a threat, he might lose his right of recourse when eviction is complete and he is unable to prove that there was a good reason for not following the rules. ${ }^{21}$ The onus of proof therefore shifts from the seller to the buyer where the rules were not followed. ${ }^{22}$ The most likely and valid reason for a buyer not to follow the rules would be where the buyer is able to prove that the third party had an unassailable title ${ }^{23}$ (such as being the true owner) or that the seller had a defective title. ${ }^{24}$

\subsubsection{The rules}

The buyer must comply with certain rules as soon as eviction threatens. Firstly, the rules prevent the buyer from surrendering or relinquishing the merx. Secondly, the buyer must notify the seller of the threatening eviction. The purpose of the notification is to give the seller an opportunity to assist the buyer or to put up a defence against

16 Par Excellence Colour Printing (Pty) Ltd v Ronnie Cox Graphic Supplies (Pty) Ltd 19831 SA 295 (A).

17 Glaston House (Pty) Ltd v Inag (Pty) Ltd 19772 SA 846 (A).

18 Own emphasis.

19 See Nagel Commercial Law 220, where the writers also refer to this time period as the time 'when eviction is imminent'. See also Nagel 2005 SA Merc LJ 375-381; Kerr and Glover "Sale" paras 75-86.

20 Nagel Commercial Law 220.

21 Nagel Commercial Law 220-221. See also Kahn Principles of Sale and Lease 27-28.

22 Sharrock Business Transactions Law 291-292.

23 See Göbel Franchises CC v Kadwa 20075 SA 456 (C) 466-467, where the court held that a buyer needs only to prove an unassailable title on a balance of probabilities.

24 Nagel Commercial Law 220. See also Sharrock Business Transactions Law 219; Nunan v Meyer 190522 SC 203; Grand National Transport (Pty) Ltd v Du Plessis 19892 SA 495 (W). 
the third party. ${ }^{25}$ When the seller receives notification in terms of the rules, the seller has a choice to make. The seller can choose to take cession of the buyer's rights and duties, assist the buyer and furnish the necessary proof of title, be joined as a party to the lawsuit, or simply do nothing. ${ }^{26}$ If the seller chooses to do nothing, he cannot later argue that the buyer should have resisted the third party's claim more energetically or skilfully, for it was open to him (the seller) to have taken steps to protect himself and the buyer. ${ }^{27}$

Where the seller decided to do nothing (or where the buyer did not effectively notify the seller) the buyer must put up a forcible, virile, vigorous defence. The circumstances of each case will determine what a vigorous defence is. ${ }^{28}$ Putting up a vigorous defence does not, however, mean that the buyer is obliged to resist the third party's claim at all costs; it suffices if he takes reasonable steps to defend the legal proceedings. ${ }^{29}$

\subsection{Buyer's right of recourse}

\subsubsection{Total eviction}

In Alpha Trust (Edms) Bpk $v$ Van der Watt ${ }^{30}$ the court held that it would be unfair against the innocent purchaser if he or she were entitled to claim the value of the merx only at the time of eviction. ${ }^{31}$ This is so because eviction gives rise to contractual (and not delictual) liability. ${ }^{32}$ The court did not accept as authority the obiter remark in Lammers and Lammers $v$ Giovanni, ${ }^{33}$ according to which the purchaser

25 Nagel Commercial Law 220. See also Sharrock Business Transactions Law 219; Nunan v Meyer 190522 SC 203; Grand National Transport (Pty) Ltd v Du Plessis 19892 SA 495 (W).

26 Nagel Commercial Law 220-221.

27 Sharrock Business Transactions Law 291. See also Lammers and Lammers v Giovannoni 19553 SA 385 (A) 388.

28 Nagel Commercial Law 221.

29 Göbel Franchises CC v Kadwa 20075 SA 456 (C). See also Sharrock Business Transactions Law 291.

30 Alpha Trust (Edms) Bpk $v$ Van der Watt 19753 SA 734 (AD).

31 Alpha Trust (Edms) Bpk v Van der Watt 19753 SA 734 (AD) 749.

32 Alpha Trust (Edms) Bpk $v$ Van der Watt 19753 SA 734 (AD) 740.

33 Lammers and Lammers $v$ Giovannoni 19553 SA 385 (A). 
would be entitled to the value of the merx only at the time of eviction. The court also rejected the argument that the purchaser would be placed in a better position after his eviction because he had the use of the merx for a certain period at no cost, because the cost-free use of the merx is for the account of the true owner (and not that of the seller). ${ }^{34}$ Not compelling the seller to return the whole of the purchase price would allow him to benefit from his own improper conduct. ${ }^{35}$ It must also be borne in mind that, in the meantime, the seller had had the use of the purchaser's money. ${ }^{36}$ Obiter, the court remarked that where the merx is of a rapidly wearing or consumable nature, it is possible that the purchaser, having used it for a reasonable period of time, would not always be entitled to repayment of the full purchase price upon eviction. In such a case, the court could modify the amount which the seller should repay to the purchaser. ${ }^{37}$ The court held that upon eviction, the innocent purchaser is entitled to the repayment of the purchase price already paid, cancellation of the contract of sale, and damages for his full id quod interest. ${ }^{38}$ The fact that the buyer has had the use of the merx prior to eviction does not affect the buyer's right of recovery. ${ }^{39}$ The case has been severely criticised, ${ }^{40}$ the main point of criticism being that by not taking into account the benefit of using the merx, the buyer was placed in a better patrimonial position than that in which he found himself before eviction. ${ }^{41}$

Upon being evicted the buyer is entitled to any increase in the value of the merx (provided it did not come about as a result of unforeseen circumstances), any costs incurred in defending an action by the true owner and any further loss occasioned by the eviction (provided the loss was reasonably foreseeable by the parties at the time of the conclusion of the contract). ${ }^{42}$

\footnotetext{
34 Alpha Trust (Edms) Bpk $v$ Van der Watt 19753 SA 734 (AD) 749.

35 Alpha Trust (Edms) Bpk $v$ Van der Watt 19753 SA 734 (AD) 749.

36 Alpha Trust (Edms) Bpk $v$ Van der Watt 19753 SA 734 (AD) 749.

37 Alpha Trust (Edms) Bpk $v$ Van der Watt 19753 SA 734 (AD) 749-750.

38 Alpha Trust (Edms) Bpk v Van der Watt 19753 SA 734 (AD) 755.

39 Katzeff $v$ City Car Sales (Pty) Ltd 19982 SA 644 (C).

40 Katzeff $v$ City Car Sales (Pty) Ltd 19982 SA 644 (C) 52.

41 Katzeff $v$ City Car Sales (Pty) Ltd 19982 SA 644 (C) 52.

42 Sharrock Business Transactions Law 292. See also Watt $v$ Standard Bank National Industrial Credit Corporation 19822 SA 47 (D).
} 
Eviction by the seller constitutes a breach of contract in the form of repudiation. ${ }^{43}$ The buyer will have a choice of either accepting the repudiation and cancelling the sale or rejecting the repudiation and enforcing the contract. ${ }^{44}$ The buyer may not, however, claim restoration of possession from the seller and may only claim repayment of the purchase price and compensation for loss under the actio empti. ${ }^{45}$

\subsubsection{Partial eviction}

In terms of Lammers and Lammers $v$ Giovanni, ${ }^{46}$ two possibilities exist where the buyer is partially evicted. Firstly, where the buyer is left with so little of the merx that a reasonable person would not have bought it, the buyer may cancel the agreement and claim repayment of the purchase price as well as damages (provided that he offers to return the remains of the merx to the seller). ${ }^{47}$ Secondly, where the portion evicted is not substantial and the remainder of the merx can be effectively used, the buyer may retain the merx and claim a pro rata repayment of the purchase price from the seller. ${ }^{48}$

\subsection{Where the buyer has no or limited right of recourse}

The buyer will not have a right of recourse where the eviction was caused by something beyond the parties' control (for example vis maior) or where the buyer's claim has prescribed. ${ }^{49}$ The seller will not be liable where the buyer knew that the seller was not the owner of the merx or where the seller made such a fact known to the buyer..$^{50}$ The seller will, however, be liable where the cause of eviction came into ex-

43 Kahn Principles of Sale and Lease 29 fn 195.

44 Kahn Principles of Sale and Lease 29 fn 195.

45 Kahn Principles of Sale and Lease 29 fn 195. See also Kerr Sale and Lease 187, where the writer states that the actio empti may also be used when the action is based on a failure to transfer ownership.

46 Lammers and Lammers v Giovannoni 19553 SA 385 (A).

47 Nagel Commercial Law 221.

48 Nagel Commercial Law 221.

49 Nagel Commercial Law 222.

50 Nagel Commercial Law 222. 
istence prior to the conclusion of the contract or after the conclusion of the contract but due to the seller's fault. ${ }^{51}$

\subsection{Exclusion of warranty against eviction}

In Vrystaat Motors $v$ Henry Blignaut (Edms) Bpk $k^{52}$ the court held that even where the warranty against eviction is excluded as part of an exemption clause, the evicted buyer may still cancel the agreement and claim for the repayment of the purchase price. According to the court, only the recovery of damages in terms of a warranty against eviction may be reduced or excluded by agreement. ${ }^{53}$

The above position was confirmed in Van der Westhuizen $v$ Arnold, ${ }^{54}$ where Lewis AJA held that the most fundamental obligation of the seller, namely the duty to give undisturbed possession of the merx, cannot be excluded by means of an exemption clause in the contract.

In Plit v Imperial Bank $L t d^{55}$ the question was if a warranty against eviction was excluded in an instalment sale agreement between the bank (the seller) and the buyer. The Supreme Court of Appeal held that in casu the parties intended for the warranty against eviction to be excluded. ${ }^{56}$ Neither the Supreme Court of Appeal nor the court a quo ruled on the question of whether, though the warranty is excluded, a buyer may still be able to reclaim the purchase price. ${ }^{57}$ Naudé states that in casu the only situation where the buyer will not be able to reclaim the purchase price is where the buyer tacitly agreed to assume the risk of uncertainty as to the seller's title to the

51 Nagel Commercial Law 222.

52 Vrystaat Motors v Henry Blignaut (Edms) Bpk 19962 SA 448 (A).

53 Vrystaat Motors v Henry Blignaut (Edms) Bpk 19962 SA 448 (A) 450.

54 Van der Westhuizen $v$ Arnold 20026 SA 453 (SCA) 468-469.

55 Plit v Imperial Bank Ltd 20071 SA 315 (SCA).

56 Plit v Imperial Bank Ltd 20071 SA 315 (SCA) 321.

57 Plit v Imperial Bank Ltd 20071 SA 315 (SCA) 322. 
property sold. ${ }^{58}$ The writer correctly argues that the warranty of eviction can never be excluded in toto. ${ }^{59}$

\section{The legal position when the Consumer Protection Act 68 of 2008 is ap- plicable}

\subsection{Application of the Act}

No provision of the CPA can be discussed without taking note of the application of the Act. The Act is applicable to the supply ${ }^{60}$ of goods ${ }^{61}$ and services ${ }^{62}$ in the ordinary course of business of a supplier ${ }^{63}$ for consideration ${ }^{64}$ to a consumer ${ }^{65}$ It is important to note that there will be a large number of sale agreements that will fall outside the ambit of the $\mathrm{Act}^{66}$ and that in those instances the common law position would still apply. Where for example a seller sells (supplies) goods in terms of a once-off transaction (in other words the sale is not part of the seller's ordinary course of business), the Act will not be applicable. This would be the case where A sells his motor vehicle or his home ${ }^{67}$ to $\mathrm{B}$. Where, however, A sells his motor vehicle as a dealer or his house as a developer (in the ordinary course of his business), the CPA will apply. In the case of consumer sales agreements where the consumer is a juristic person ${ }^{68}$ with an annual turnover or asset value, at the time of the transaction, that equals or

58 Naudé 2007 Annual Survey of SA Law 1041-1042.

59 Naudé 2007 Annual Survey of SA Law 1042.

60 The definition of 'supply' in terms of $\mathrm{s} 1$ in relation to goods includes sell.

61 The definition of 'goods' 'supply' in terms of $s 1$ inter alia includes any tangible object, intangible object, a legal interest in land or any other immovable property, gas, water and electricity.

62 The definition of 'service' in $\mathrm{s} 1$.

63 Excluding once-off transactions in terms of $s 5$.

64 The definition of 'consideration' in terms of $s 1$ means anything of value given and accepted in exchange for goods or services including money.

65 In terms of $s 1$ the definition of 'consumer' includes a natural person, juristic person, a user of the particular goods, recipient or beneficiary to those goods as well as a franchisee. in terms of $s$ $5(6)$ (a) this includes members of a club, trade union, association, society or other collectivity.

66 Section 5 of the Act deals with application. S 5(2)(d) provides, for example, that in the case of a sale agreement that is also a credit agreement in terms of the National Credit Act 34 of 2005, only the goods that are the subject of the credit agreement will not be excluded from the application of the CPA.

67 Section 1 of the CPA. The definition of 'goods' includes movables and immovable (interest in land).

68 The definition of 'juristic person' ito $s 1$ includes a body corporate, partnership or association or trust. 
exceeds the threshold value ${ }^{69}$ determined by the Minister of Trade and Industry, the Act is not applicable. ${ }^{70}$

\subsection{A consumer's right to assume that the supplier is entitled to sell the goods}

Section 44 forms part of the fundamental right of a consumer to fair, just and reasonable terms and conditions. ${ }^{71}$ Every consumer has a right to assume, and it is an implied provision of every transaction or agreement, that the supplier has the legal right, or the authority of the legal owner, to supply those goods. ${ }^{72}$ In the case of an agreement to supply goods, the supplier will have a legal right or the authority of the legal owner to sell the goods at the time when the title to those goods is to pass to the consumer. ${ }^{73}$

I am in agreement with Sharrock that section 44 is badly drafted. ${ }^{74}$ Nagel $^{75}$ refers to the supply of goods as the supply of goods per se, in other words where no transaction or agreement is involved. Although the consumer has a right in terms of the CPA to assume $^{76}$ that the seller has the legal right to sell the goods, this does not result in the seller having a duty to guarantee the transfer of ownership. Even where the buyer has a right to assume that the seller has a right to sell the goods at the time the title to those goods (ownership) is to pass to the buyer, ${ }^{77}$ there is no obligation on the seller to transfer ownership in terms of the Act. One would assume that the main purpose of the section was to prevent the seller from selling stolen goods. Sharrock correctly argues that it is unclear whether or not the legislature intended to reaffirm or abandon the common law rule that a person may validly sell or let goods of which he

69 In terms of GN 294 in GG 34181 of 1 April 2011: two million rand.

70 Section 5(2)(b).

71 Chapter 2 Part F.

72 Section 44(1)(a).

73 Section 44(1)(b)(i).

74 Sharrock Business Transactions Law 604.

75 Nagel Commercial Law 222

76 Own emphasis.

77 Nagel Commercial Law 214. 
is not the owner (res aliena).$^{78}$ The section is silent on any remedy if the required legal right or authority does not exist or does not come into existence. ${ }^{79}$ Van Eeden states that the two most important effects of section 44(1)(a) and (b) are firstly that the consumer can assert that he legitimately assumed that the seller had the right or the authority of the legal owner to sell the goods, ${ }^{80}$ and secondly, that the seller is not required to make a pre-contractual statement to the consumer that he (the seller) is the owner or has the authority to sell the goods, or to include a statement to such an effect in the agreement itself as it is provided for in the Act. ${ }^{81}$

\subsection{Liability for charges and encumbrances}

In terms of section 44(1)(c), the supplier is fully liable for any charge or encumbrance pertaining to the goods in favour of any third party unless such a charge or encumbrance is disclosed in writing to the consumer before the transaction or agreement is concluded $^{82}$ or the supplier and consumer have colluded to defraud the third party. ${ }^{83}$

If one were to look at section 44(1)(c) from the viewpoint of a seller, the section provides that the buyer can assume - and it is an implied term (the buyer does not have to be informed thereof because it forms part of the consumer sale agreement as an implied term) - that the seller will not be fully liable or that the seller will only have limited liability for charges or encumbrances relating to the merx. The proviso in terms of section $44(1)(c)(i)$ is that the seller can escape or limit his liability only where the charge or encumbrance was disclosed to the buyer in writing before the conclusion of the agreement. It can be argued, therefore, that the seller has a duty only to disclose the charge or encumbrance to the buyer (in writing, prior to the conclusion of the agreement) and $n o t^{84}$ the fact that the seller will limit his own liability by doing so, because in terms of section 44(1) it is an implied term of the consumer sale agreement.

\footnotetext{
78 Sharrock Business Transactions Law 604.

79 Sharrock Business Transactions Law 604.

80 Van Eeden Guide to the Consumer Protection Act 221.

81 Van Eeden Guide to the Consumer Protection Act 221.

82 Section 44(1)(c)(i).

83 Section 44(1)(c)(ii).

84 Own emphasis.
} 
The seller is fully liable to a third party for any charge or encumbrance pertaining to the goods in favour of that third party if the seller and the buyer colluded to defraud the third party. ${ }^{85}$

No remedy is available to a consumer in terms of section 44(1) where the charges or encumbrances were not disclosed.

\subsubsection{The meaning of 'charge' or 'encumbrance'}

Neither 'charge' nor 'encumbrance' is defined in the CPA and it is assumed that the definitions as established through case law ought to apply. In Hollins $v$ Registrar of Deeds ${ }^{86}$ Innes CJ defined 'encumbrance' as a real burden on the land, a portion of the dominium parted with by the owner. ${ }^{87}$ This does not mean any reference to the land in a contract, giving a mere action in personam (personal right) to the contracting party. In Glaston House (Pty) Ltd $v$ Inag (Pty) Ltd ${ }^{88}$ the court found the existence of a monument embedded in the building which prevented re-development of the building to be an encumbrance. In Ex Parte Fleishman $N O^{89}$ the court held that rights are not encumbered unless a party received a real right therein. Leases on property were considered to be encumbrances in Estate Marks v Pretoria City Council. ${ }^{90}$ In certain instances estate duty could be described as an encumbrance or as a tax. ${ }^{91}$ The court held in Lorentz $v$ Melle and Others ${ }^{92}$ that the general rule is that a contract cannot bind a person who is not a party to it. According to the court, contractual duties, however, can be or are transmitted where the duty constitutes a real encumbrance on land, by the acquisition of such land. In Port Edward Town Board $v$ Kay ${ }^{93}$ zoning was held to be a legally enforceable encumbrance relating to the property and

\footnotetext{
85 Section 44(1)(c)(ii).

86 Hollins $v$ Registrar of Deeds 1904 TS 603.

87 Hollins $v$ Registrar of Deeds 1904 TS 603608.

88 Glaston House (Pty) Ltd v Inag (Pty) Ltd 19772 SA 846 (A) 848.

89 Ex Parte Fleishman 19834 SA 866 (E).

90 Estate Marks v Pretoria City Council 19693 SA 227 (A).

91 Albert $v$ Pearse and The Master 19731 SA $827(\mathrm{~N})$.

92 Lorentz v Melle 19783 SA 1044 (T).

93 Port Edward v Kay 19963 SA 664 (A).
} 
its effect would be to inhibit the marketing of that property; it was a restriction that the owner had to overcome.

In Ex Parte Estate Bostock ${ }^{94}$ a 'charge' was regarded as normal income tax, super tax, personal and provincial income tax and a personal savings fund levy (basic tax). The court held that the word 'charge' is a burden on property or a person and includes whatever constitutes a burden on property such as rents, taxes, liens, costs, and expenses incurred, usually in the plural.

'Charging' in the commercial sense can be defined as 'to impose a burden, duty, obligation, or lien; to create a claim against property; to impose a tax, duty, or trust; to bill or invoice, and can also include the price of, or rate for, something'. ${ }^{95}$

\subsection{Guarantee of quiet possession}

In terms of section $44(1)(d)$ the supplier guarantees that the consumer is to have and enjoy quiet possession ${ }^{96}$ of the goods, subject to any charge or encumbrance disclosed. Because no definition is given to 'quiet possession' it is unclear what is meant by the term and whether 'quiet possession' is synonymous with the common law term of vacua possessio or undisturbed possession of the merx. It is important to establish whether or not the guarantee of quiet possession is an entrenchment of the common law warranty against eviction into the CPA. Jacobs et al are of the opinion that section $44(1)(d)$ corresponds with a buyer's common law warranty against eviction. ${ }^{97}$ Van Eeden explains that in terms of the common law, the seller can also undertake expressly or would be deemed to have undertaken (unless specifically excluded by agreement) that the buyer would enjoy 'quiet possession'. ${ }^{98}$ It would seem that the writer also considers the guarantee of quiet possession as a confirmation of the buyer's common law warranty against eviction.

94 Ex Parte Estate Bostock 1945 CPD 58 64-65.

95 Farlex Date Unknown bit.ly.

96 Section $44(1)(d)$.

97 Jacobs, Stoop and Van Niekerk 2010 PER 350.

98 Van Eeden Guide to the Consumer Protection Act 220. 
If section $44(1)(d)$ is a confirmation of the common law warranty against eviction, two important issues need to be addressed. The first of these is whether or not the buyer still needs to follow the rules as established in terms of our common law. ${ }^{99}$ Does the buyer still need to put up a vigorous defence, not readily relinquish the merx, and notify the seller? The purpose of the rules is to give the seller an opportunity to prove his title or to assist the buyer and ensure that the buyer will have a claim if he is evicted. ${ }^{100}$ Because of the implied term and warranty contained in section 44 it seems unnecessary for the buyer to follow the rules. There is nothing in the section or the Act that would indicate that if the buyer does not follow the common law rules, the onus of proof would be on the buyer to prove that the seller had a defective title or that the third party had an unassailable title ${ }^{101}$ because the buyer has a right to assume that the seller has the right or the authority to the sell the goods, and the fact that the seller guarantees quiet possession in terms of section 44 of the Act has the effect that such an onus on the buyer is done away with.

\subsubsection{Absence of remedies in section 44}

As stated earlier, section 44 does not provide any remedies, and it is argued that the provisions of section 2(10) keep intact the remedies available to a buyer in terms of the common law. Section 2(10) provides that no provision of the CPA may be interpreted so as to preclude a consumer (a buyer) from exercising any right he may have in terms of the common law. The buyer may therefore still rely upon the cancellation of the consumer agreement, repayment of the purchase price, and a claim for damages.

99 See 2.2.1 above.

100 Nagel Commercial Law 220-221.

101 See 2.2 above. 


\subsection{Right or claim of third party to goods}

The wording of section 44(2) is obscure. Sharrock explains that the liability referred to in the section would appear to be a liability in damages for loss suffered by the third party pursuant to the unauthorised supply of the goods, such as loss suffered because of the consumption of the goods by the buyer. ${ }^{102}$ It is difficult to see how a seller may limit his liability towards a third party (not a party to the contract) where he (the seller) disclosed certain charges and encumbrances to the consumer ${ }^{103}$ pertaining to the goods and as part of the sale agreement with the consumer. ${ }^{104}$ The only possible situation where this would apply (where the consumer would be liable for the remainder of the infringement) would be where the consumer (the buyer had knowledge of the seller's defective title or further charges and encumbrances.

\subsection{The exclusion of the liability of the seller for the eviction of the buyer in consumer sale agreements: in search of answers within the Act}

As established by case law, ${ }^{105}$ the warranty against eviction may be limited by way of agreement but never completely excluded. This means that parties may exclude a claim for damages in terms of a warranty against eviction but not the cancellation of the agreement and the repayment of the purchase price. May the supplier exclude a claim for damages based on section 44 in the consumer sale agreement? Two provisions in the Act seem to be in conflict with each other. In terms of section 2(10) the buyer will always have a right to cancel the agreement and to claim the purchase price as well as damages. Section 48(1)(c), on the other hand, leaves a back door open for sellers to limit the claim for damages based on a warranty against eviction as long as the terms and conditions upon which such a waiver of a right by the buyer is not based on unfair, unreasonable or unjust terms and conditions. Section 48(1)(c) does not prohibit the waiver of the supplier's liability, only the way in which such terms are formulated in the consumer sale agreement, and may therefore not be based on a term that is unreasonable, unjust or unfair. Section $48(2)$ provides that a

102 Sharrock Business Transactions Law 605.

103 Own emphasis.

104 Own emphasis.

105 See 2.5 above. 
term or condition is regarded as unfair, unreasonable or unjust where it is excessively one-sided in favour of a non-consumer or so adverse to a consumer that it is inequitable, ${ }^{106}$ or where a consumer relied upon a misrepresentation or term as contemplated respectively in sections 41 and $49 .{ }^{107}$ It is clear from section $4(4)(b)$ that the exclusion or limitation of a seller's liability is not prohibited per se, but will be interpreted against the seller (supplier). Section 4(4)(b) provides that any contract must be interpreted to the benefit of the consumer so that any restriction, limitation, exclusion or deprivation of a consumer's legal rights set out in such a document or notice is limited to the extent that a reasonable person would ordinarily contemplate or expect. $^{108}$

If the warranty may not be excluded (nor the claim for damages) in terms of the CPA, the court would most likely have come to a different conclusion in Van der Westhuizen $v$ Arnold. ${ }^{109}$ The clause stating that the seller had given 'no warranty whatsoever' seen through the eyes of the Act would be regarded as an unfair, unjust and unreasonable term and would not be enforceable on the buyer. In terms of section 49 of the CPA, for example, the acknowledgement of any fact by the consumer in a contract must be drawn to the attention of the consumer in plain language. Therefore stating that the seller had given no warranty at all should comply with the requirements of section 49. If it does not, the term will be regarded as unfair, unreasonable and unjust in terms of section 48(2)(d). Section 48(2)(d) provides that a term is unfair, unreasonable or unjust if the agreement was subject to a term that is unfair $^{110}$ or the fact, nature and effect of that term was not drawn to the attention of the consumer in terms of section $49 .{ }^{111}$ Regulation 44 to the Act further gives a list of contract terms which are presumed not to be fair and reasonable. A term is unfair if it has the purpose of forcing the consumer to indemnify the supplier against liability incurred by it to third parties ${ }^{112}$ or excludes or hinders the consumer's right to take legal

\footnotetext{
106 Section 48(2)(a) and (b).

107 Section 48(2)(c) and (d).

108 Section 4(4)(b); taking into account the circumstances, content of the document and the manner in which it was presented.

109 Van der Westhuizen $v$ Arnold 20026 SA 453 (SCA).

110 Section 48(2)(d)(i): "unfair, unreasonable, unjust or unconscionable".

111 Section 48(2)(d)(ii).

112 Regulation 44(3)(e).
} 
action or exercise any other legal remedy. ${ }^{113}$ Kahn is of the opinion that the warranty against eviction, including the claim for damages, may not be excluded in terms of the Act. ${ }^{114}$

The solution to the problem of the contrasting provisions (section 2(10) resulting in no exclusion of the warranty whatsoever versus an exclusion of a claim for damages provided that such a waiver of the buyer's right to claim damages is not unfair, unreasonable or unjust as provided for in terms of section 48(1)) lies within the Act itself. Section 4 deals with the realisation of consumer rights and provides that the court must $t^{115}$ develop the common law as necessary to improve the realisation and enjoyment of consumer rights generally, and in particular by persons contemplated in section 3(1)(b). ${ }^{116}$ Section 4(3) further provides that if any provision of the Act, read in its context, can reasonably be construed to have more than one meaning, the meaning that best promotes the spirit and purposes of this Act, and will best improve the realisation and enjoyment of consumer rights, must be followed. The rule of thumb seems to be: whatever route is most beneficial to the consumer and most in line with the purposes of the Act should be followed.

\section{$4 \quad$ In search of an answer: United Kingdom}

\subsection{Section 12 of the Sales of Goods Act 1979}

Section 12 of Sales of Goods Act 1979 (SOGA) provides that it is an implied term ${ }^{117}$ on the part of the seller that in the case of a sale he has a right to sell the goods, and in the case of an agreement to sell, he will have such a right at the time when the property is to pass. ${ }^{118}$ In a contract of sale the goods are free, and will remain free until the time when the property is to pass, from any charge or encumbrance ${ }^{119}$ not

\footnotetext{
113 Regulation 44(3)(x).

114 Kahn Principles of Sale and Lease 29-30.

115 Own emphasis.

116 Section 3(1)(b) includes low-income, illiterate, isolated vulnerable consumers.

117 Own emphasis.

118 Section 12(1) SOGA.

119 Own emphasis.
} 
disclosed or known to the buyer before the contract is made, and the buyer will enjoy quiet possession ${ }^{120}$ of the goods except so far as it may be disturbed by the owner or other person entitled to the benefit of any charge or encumbrance so disclosed or known. ${ }^{121}$ Section 12(3) and (4) states that in a contract of sale in which there appears to be an intention that the seller should transfer only such title as he or a third person may have, there is an implied term that all charges or encumbrances known to the seller and not known to the buyer have been disclosed to the buyer before the contract is made. There is also an implied term in the sale of goods that neither the seller, a third party nor anyone claiming through or under the seller or that third person otherwise than under a charge or encumbrance disclosed or known to the buyer before the contract is made, shall disturb the buyer's quiet possession. ${ }^{122}$

\subsubsection{General}

SOGA applies to the sale of corporeal movable goods only. ${ }^{123}$ This includes consumer sales. ${ }^{124}$ According to Dobson and Stokes, ${ }^{125}$ section $12(5 \mathrm{~A})$ makes it clear that the implied term referred to in section $12(1)$ is a condition, and the term used in section 12(2) with regard to the buyer's quiet possession is a warranty. Like section $44(1)$ of the CPA, ${ }^{126}$ section 12(1) of SOGA does not require the seller to be the owner, nor that he should acquire title before transferring the goods, but merely that he must have the right to sell. ${ }^{127}$ The expression 'right to sell' is wider than the word 'title' and it means that the buyer is protected not only when the seller has no title but also when he is prevented from selling the goods by a legal process such as an injunction. Thus the right to sell includes the 'legal power to sell'. ${ }^{128}$

120 Own emphasis.

121 Section 12(2) SOGA.

122 Section 12(5) SOGA.

123 Sections 1 and 2 SOGA.

124 Dobson and Stokes Commercial Law 162-163.

125 Dobson and Stokes Commercial Law 103.

126 See above.

127 Dobson and Stokes Commercial Law 103.

128 Ervine Consumer Law in Scotland 21. 
Section 12(1) also ${ }^{129}$ draws a distinction between 'to sell' and 'an agreement to sell'. 'An agreement to sell' goods is interpreted to mean that if the transfer of property is to take place at a future time or is subject to the later fulfilment of a condition, the buyer will have that right at the time when the property is to pass. ${ }^{130}$

Section 12(3) and (4) provide specifically for the sale of goods where the seller has a limited title and the provision of such a limited title should also be the intention of the parties. An example given by Dobson and Stokes is that of a seller who has only a 'finder's title'. ${ }^{131}$ A finder does have a title to the goods but only a possessory title, which is subject to the title of the original owner. A finder who sells goods without first disclosing that he has only a finder's title is in breach of the conditions of section 12 . However, if the seller has disclosed that fact so as to indicate only a transfer of a possessory title, the buyer will have no claim in terms of section 12(3) based on the limited title of the seller. Even if the limited title of the seller is disclosed to the buyer, the seller must in addition disclose all charges and encumbrances known to him at the time of the conclusion of the contract. ${ }^{132}$

\section{2 'Charges and encumbrances'}

Dobson and Stokes describe 'charges and encumbrances' in terms of section 12 of SOGA as rights that someone else has over the goods. An example is where someone has a lien over the goods (a right to retain possession of the goods until a debt is paid). ${ }^{133}$ Importantly, the writers state that even where the goods are subject to a charge or encumbrance the seller can still sell the goods and will not be in breach of section 12 of SOGA and the warranty of quiet possession, provided of course that the seller informed the buyer of this fact prior to the conclusion of the contract. ${ }^{134}$

129 Section 44(1)(a)(b). See also 3.2 above.

130 Evans-Jones and Smith "Sale" 273.

131 Dobson and Stokes Commercial Law 105.

132 Dobson and Stokes Commercial Law 105.

133 Dobson and Stokes Commercial Law 104.

134 Dobson and Stokes Commercial Law 105. 


\subsection{Interpretation of section 12 by courts}

The Scottish case of McDonald $v$ Provan (of Scotland Street) Ltd ${ }^{135}$ is reminiscent of the facts in Vrystaat Motors $v$ Henry Blignaut (Edms) Bpk. ${ }^{136}$ In McDonald the seller sold a stolen vehicle in good faith to the buyer. Three months after the sale the vehicle was taken from the buyer by the police because at least part of the motor vehicle was stolen property. The buyer (McDonald) successfully sued for damages for the breach of the implied warranty of quiet possession in terms of section 12 of SOGA.

Rowland $v$ Divall $^{137}$ also involved the sale of a motor vehicle. The buyer used it for four months before discovering that it had been stolen and that the seller was not the true owner. The buyer returned the car to the true owner and sued the seller for the return of the purchase price, based on section 12 of SOGA. The court held that the four-months use was regarded as irrelevant and no set-off (a sum deducted to take into account any advantages received or detriments suffered) was allowed for the four-months use. The case has been the subject of considerable criticism in the United Kingdom and writers such as Dobson and Stokes ${ }^{138}$ argue that it is inequitable for the buyer to have had over three months' free use of the motor vehicle. (The criticism of the case is remarkably similar to that levelled at the South African case of Alpha Trust (Edms) Bpk v Van der Watt.) $)^{139}$

In Niblett Ltd $v$ Confectioners Materials' $\mathrm{Co}^{140}$ the court found that if there is a breach of section 12 (and eviction took place) the buyer can reject the goods and recover the full price, even if he has done something which would otherwise amount to an acceptance of the goods. ${ }^{141}$

135 McDonald v Provan (of Scotland Street) Ltd 1960 SLT 231.

136 Vrystaat Motors v Henry Blignaut (Edms) Bpk 19962 SA 448.

137 Rowland v Divall 19232 KB 500.

138 Dobson and Stokes Commercial Law 103.

139 Alpha Trust (Edms) Bpk v Van der Watt 19753 SA 734 (A).

140 Niblett Ltd v Confectioners Materials' Co 19213 KB 387.

$141 \mathrm{In}$ terms of Scottish law the buyer usually loses his right to reject the goods if he committed an act of acceptance. The case of a warranty of quiet possession seems to be an exception to this general rule. 
In Rubicon Computer Systems Ltd $v$ United Paints Ltd ${ }^{142}$ the seller attached a time lock on a computer system which after a period of time denied the buyer access to the same. The court held that this breached section 12(2)(b) in that the buyer could not enjoy quiet possession. In this case it was held that the seller disturbed the buyer in his quiet possession, and not a third party. Although English decisions on the sale of goods do not limit the warranty of quiet possession to interference by the seller, some link with the seller is required. ${ }^{143}$

An interesting case with regard to the time period in which the buyer has a right to enjoy quiet possession is that of Microbeads $v$ Vinhurst Road Markings. ${ }^{144}$ The court held that the warranty as to quiet possession relates not only to the time when the contract is concluded but also to the future, because of the wording of section 12 that the buyer will enjoy quiet possession. The warranty of quiet possession is a continuing warranty and not limited solely to a defective title existing at the time of the conclusion of the contract. ${ }^{145}$

\subsection{Remedies available to the buyer}

It is clear from the discussion of the applicable case law above that where the buyer is evicted from his quiet possession in terms of section 12, the buyer may cancel the agreement, reclaim the purchase price and claim damages.

Remedies are also provided in terms of SOGA, where there is a breach of warranty by the seller. In terms of section 53 the buyer may reclaim the purchase price or claim for a reduction in the purchase price and damages where the breach is not of a material nature. (This would be similar to the position in terms of South African law

142 Rubicon Computer Systems Ltd v United Paints Ltd 20002 TCLR 453.

143 Evans-Jones and Smith "Sale" 278.

144 Microbeads v Vinhurst Road Markings 19751 WLR 218.

145 Evans-Jones and Smith "Sale" 276. The writers refers to the South African case of Van Staden $v$ Pretorius $19651 \mathrm{SA} 852$ (T) at 853, where the court held that the eviction must either exist at the time of the conclusion of the contract or if arising subsequent thereto, is due to some act on the part of the seller. 
when the buyer is only partially evicted. $)^{146}$ In terms of section 54 the buyer may also claim interest on the purchase price. ${ }^{147}$

\subsection{Exclusion of warranty of quiet possession prohibited}

Section 20(1)(a) of the Unfair Contract Terms Act 1977 prohibits any exclusion of the implied terms of section 12 of SOGA in a contract for the sale of goods. Section 6 of the same Act $^{148}$ provides that in the case of the sale of consumer goods, the supplier (the seller) is prohibited from exempting himself from any liability under section 12 of SOGA and can therefore never exclude or restrict the warranty of quiet possession. It seems that the warranty of quiet possession enjoys additional protection in the case of consumer sales.

\section{Comments}

\subsection{Implied term of the right to sell or the authority to sell not a guarantee of the transfer of ownership}

It is clear that though the consumer has the right to assume that a supplier has the right to sell or the authority to sell goods, this implied term as provided for in terms of section 44(1) of the CPA is not a guarantee of the transfer of ownership. In this regard the common law position remains unchanged and the nemo plus iuris ${ }^{149}$ principle also remains intact. This approach is also in line with the appropriate foreign law. ${ }^{150}$

146 See Lammers and Lammers v Giovannoni 19553 SA 385 (A).

147 Section 15B of SOGA, which applies only to Scotland, provides that the buyer may repudiate (cancel) the agreement only where the breach of warranty is material. Disturbing the buyer in his quiet possession seems to be regarded as material, when looking at the interpretation and awarding of remedies by the courts, as discussed in 4.3 above.

148 Unfair Contract Terms Act 1977.

149 The principle that no person may transfer more rights than he himself possesses.

150 Section 12 SOGA as discussed in 4.1.1. 


\subsection{Charges and encumbrances}

In terms of South African case law, ${ }^{151}$ an encumbrance is some form of real right connected to immovable property. A charge, on the other hand, can be a burden on either property (including movable property) or a person and includes taxes, rents, levies, debts and liens. ${ }^{152}$ These definitions seem to be most appropriate to apply in the case of section 44 of the CPA and also consistent with definitions given to 'charge' or 'encumbrance' in terms of foreign law. ${ }^{153}$

Charges and encumbrances do not affect the validity of the sale of goods in terms of consumer sale agreements. ${ }^{154}$ Furthermore, section $44(1)$ of the CPA provides that the seller only needs to inform the buyer in writing of charges or encumbrances known to him at the time of the conclusion of the contract. The supplier does not have to explain to the buyer that by informing the buyer of the former, he (the seller) will also be restricting his own liability in the process.

\subsection{Is the guarantee of quiet possession in section 44 of the CPA an entrenchment of the common law warranty against eviction?}

The seller guarantees that the buyer will enjoy quiet possession of the merx in terms of section $44(1)(d)$. In the light of a comparative discussion in the United Kingdom (and section 12 of SOGA in particular, which has very similar wording to that of section 44 of the CPA) ${ }^{155}$ the question posed above must be answered in the affirmative. The implication of this for consumer sales in South Africa is that the buyer now has a statutorily entrenched contractual guarantee as to the undisturbed use and enjoyment of the merx. It follows, therefore, that the buyer neither needs to follow the common law rules when threatened with eviction nor bears the onus of proving that the rules were not followed because of a defective title of the seller or an unassailable title of the third party.

151 See 3.3 above.

152 See 3.3 above.

153 The United Kingdom. See 4.2 above.

154 See 4.2 above.

155 See 4.1 and 4.3 . 


\subsection{Remedies available to the buyer}

It is an unfortunate oversight on the part of the legislature not to have included any remedies for the breach of the guarantee of quiet possession in section 44(1)(d) of the Act. In fact, no provision is made for remedies for the breach of such a warranty anywhere in the Act. The remedies available to the consumer in section 56 of the Act, for instance, relate only to the quality of the goods and not to where the guarantee of quiet possession is breached.

The obvious solution regarding the lack of remedies in terms of section 44 of the Act is to revert to the common law remedies available to the buyer in the case of eviction. This is confirmed by section 2(10) of the Act. ${ }^{156}$ At common law the buyer may cancel the agreement, reclaim the purchase price and claim damages, ${ }^{157}$ bearing in mind that the buyer may utilise these remedies without a reduction of the amounts claimed for wear and tear, where the goods were of a consumable nature. ${ }^{158}$ Similar remedies are also available to a buyer in terms of applicable foreign law. ${ }^{159}$

\subsection{The exclusion of a claim for damages where the guarantee of quiet possession (warranty against eviction) is breached?}

As discussed above, ${ }^{160}$ contradictory provisions exist within the CPA on whether a seller may exclude or limit his liability for eviction of the buyer. On the one hand the seller may do so, provided the terms of such an exclusion are not unfair, unreasonable or unjust. ${ }^{161}$ Any provision in an agreement which excludes the seller's liability will be interpreted and construed against him. ${ }^{162}$ On the other hand, the Act

156 No common law right available to the consumer may be excluded where the CPA is applicable.

157 See 2.3 above.

158 The position in Alpha Trust (Edms) Bpk v Van der Watt 19753 SA 734 (A) has not been overturned by the courts and it is doubtful that the position will change with the application of the CPA to consumer sales.

159 See 4.3 and 4.4 above, where the position in the United Kingdom in terms of SOGA is discussed. Buyers are granted these remedies by the courts. Similar remedies are also provided for in the Act itself (s 53 of SOGA).

160 See 3.6 above.

161 Section 48 CPA.

162 Section 4(4)(b) CPA. 
provides that consumer rights (and remedies) must be developed and not restricted. Where there are contrasting provisions the rule of thumb should be to follow what is most beneficial to the consumer.

Taking into account section 2(10) of the Act, in terms of which no common law right of a consumer may be precluded in terms of the Act, it seems that the common law position with regard to the exclusion of a claim for damages has been amended. The seller may not exclude a claim for damages where the CPA is applicable.

To re-enforce this argument, notice should be taken of the applicable foreign law, which also prohibits the exclusion of the warranty of quiet possession. Section 2(2)(a) of the CPA provides that when interpreting the Act, applicable foreign and international law may be considered. The Unfair Contract Terms Act 1977 of the United Kingdom specifically prohibits the exclusion of the warranty of quiet possession or any remedy in terms of such a warranty in the sale of consumer goods. ${ }^{163}$

\section{Conclusion}

The common law warranty against eviction is confirmed by section 44 of the CPA. The exclusion of a claim for damages based on eviction is prohibited where the CPA is applicable.

Due to poor drafting and the inclusion of provisions from foreign legislation without having regard to the meaning of the terminology in South African law, uncertainties have crept into the Act and ironically need to be solved by reverting to the foreign legislation which the provisions of the CPA mimic. In this instance section 12 of SOGA and the interpretation thereof by the courts in the United Kingdom have provided some answers.

163 Sections 6 and 20(1)(a). See also 4.5 above. 
Solutions are also found in the South African common law and the interpretation thereof by the South African courts. It remains to be seen, however, whether the South African courts will revert to what is already entrenched in our law (the common law), or choose to look at the applicable foreign law, or both. 


\section{Bibliography}

Dobson and Stokes Commercial Law

Dobson P and Stokes W (eds) Commercial Law $7^{\text {th }}$ ed (Sweet \& Maxwell London 2007)

\section{Ervine Consumer Law in Scotland}

Ervine WCH Green's Consumer Law in Scotland $4^{\text {th }}$ ed (Thomson \& Green Edinburgh 2008)

Evans-Jones and Smith "Sale"

Evans-Jones R and Smith A "Sale" in Zimmermann R, Visser DP and Reid K (eds) Mixed Legal Systems in Comparative Perspective (Juta Cape Town 2004) 271-300

Jacobs, Stoop and Van Niekerk 2010 PER

Jacobs W, Stoop PN and Van Niekerk R "Fundamental consumer rights under the Consumer Protection Act 68 of 2008: A critical overview and analysis" 2010 PER 302-508

Kahn Principles of Sale and Lease

Kahn E Principles of the Law of Sale and Lease $2^{\text {nd }}$ ed (Juta Cape Town 2010)

Kerr Sale and Lease

Kerr AJ The Law of Sale and Lease $3^{\text {rd }}$ ed (LexisNexis Durban 2004)

Kerr 1999 SALJ

Kerr AJ "The warranty against eviction in contracts of sale" 1999 SALJ 455462

Kerr and Glover "Sale"

Kerr AJ and Glover G "Sale" in Joubert WA and Faris JA (eds) The Law of South Africa (Butterworths Durban 2000) vol 2, paras 75-86 
Nagel Commercial Law

Nagel CJ (ed) Commercial Law $4^{\text {th }}$ ed (LexisNexis Durban 2011)

Nagel 2005 SA Merc LJ

Nagel CJ "Die Regsposisie van 'n Verkoper waar Uitwinning Dreig" 2005 SA Merc LJ 375-381

Naudé 2007 Annual Survey of SA Law

Naudé T "The Law of Purchase and Sale" 2007 Annual Survey of SA Law 1041-1045

Sharrock Business Transactions Law

Sharrock R Business Transactions Law $8^{\text {th }}$ ed (Juta Cape Town 2011)

Van Eeden Guide to the Consumer Protection Act

Van Eeden E A Guide to the Consumer Protection Act (LexisNexis Butterworths Durban 2009)

\section{Register of cases}

\section{South Africa}

Albert $v$ Pearse and The Master 19731 SA 827 (N)

Alpha Trust (Edms) Bpk v Van der Watt 19753 SA 734 (A)

Becker \& Co (Pty) Ltd v Becker 19813 SA 406 (A)

Estate Marks v Pretoria City Council 19693 SA 227 (A)

Ex Parte Estate Bostock 1945 CPD 58

Ex Parte Fleishman 19834 SA 866 (E)

Glaston House (Pty) Ltd v Inag (Pty) Ltd 19772 SA 846 (A)

Göbel Franchises CC v Kadwa 20075 SA 456 (C)

Grand National Transport (Pty) Ltd v Du Plessis 19892 SA 495 (W)

Hollins $v$ Registrar of Deeds 1904 TS 603

Katzeff v City Car Sales (Pty) Ltd 19982 SA 644 (C)

Lammers and Lammers v Giovannoni 19553 SA 385 (A)

Lavers v Hein \& Far BK 19972 SA 396 (T) 
Lorentz v Melle 19783 SA 1044 (T)

Mdakane v Standard Bank of South Africa Ltd 19991 SA 127 (W)

Nunan v Meyer 190522 SC 203

Par Excellence Colour Printing (Pty) Ltd v Ronnie Cox Graphic Supplies (Pty) Ltd 1983 1 SA $295(A)$

Plit v Imperial Bank Ltd 20071 SA 315 (SCA)

Port Edward Town Board v Kay 19963 SA 664 (A)

Van der Westhuizen v Arnold 20026 SA 453 (SCA)

Van Staden v Pretorius 19651 SA 852 (T)

Vrystaat Motors v Henry Blignaut (Edms) Bpk 19962 SA 448 (A)

Watt $v$ Standard Bank National Industrial Credit Corporation 19822 SA 47 (D)

\section{United Kingdom}

McDonald v Provan (of Scotland Street) Ltd 1960 SLT 231

Microbeads v Vinhurst Road Markings 19751 WLR 218

Niblett Ltd v Confectioners Materials' Co 19213 KB 387

Rowland v Divall 19232 KB 500

Rubicon Computer Systems Ltd v United Paints Ltd 20002 TCLR 453

\section{Register of legislation}

\section{South Africa}

Consumer Protection Act 68 of 2008

National Credit Act 34 of 2005

\section{United Kingdom}

Sales of Goods Act 1979

Unfair Contract Terms Act 1977

Register of government publications

GN 294 in GG 34181 of 1 April 2011 


\section{Register of Internet sources}

Farlex Date Unknown bit.ly

Farlex Date Unknown Free Legal Dictionary bit.ly/NKYL1c [date of use 27 Jul 2012]

\section{List of abbreviations}

CPA Consumer Protection Act

PER Potchefstroom Electronic Law Journal

SALJ South African Law Journal

SA Merc LJ South African Mercantile Law Journal

SOGA Sales of Goods Act 